\title{
LOKA LOAK KEBAYORAN LAMA
}

\author{
Rinardy Tanuwijaya ${ }^{1)}$, Rudy Trisno ${ }^{21}$ \\ 1)Program Studi S1 Arsitektur, Fakultas Teknik, Universitas Tarumanagara, rinardytan@gmail.com \\ 2)Program Studi S1 Arsitektur, Fakultas Teknik, Universitas Tarumanagara, rudy@ft.untar.ac.id
}

\begin{abstract}
Abstrak
Keberadaan suatu pusat transit sebagai tempat perpindahan memunculkan titik-titik baru berkumpulnya masyarakat, yang secara tidak langsung dan spontan menjadi third place baru. Kebayoran Lama Utara, yang terletak erat dengan stasiun kereta api tidak luput oleh fenomena tersebut. Tempat penjualan barang loak yang unik dan membentuk citra menjadi marak di sekitar tapak, yang sayangnya tidak di tempat yang seharusnya. Sehingga ironi, dimana sebuah potensi yang dapat mengembangkan, menjadi sesuatu yang tidak seharusnya. Terlebih tapak merupakan titik negatif yang kurang efektif, namun ramai oleh aktivitas masyarakat. Loka Loak Kebayoran Lama, dengan metode urban retrofitting, bertujuan untuk mengembangkan area tersebut, baik di dalam tapak, lingkungan sekitar, serta masyarakatnya dalam satu sistem memenuhi fungsi baik sosial, ekonomi, maupun lingkungan berkelanjutan. Proyek terinspirasi dan memaksimalkan situasi sekitar, dengan pemanfaatan struktur ruko terbengkalai, serta pendekatan urban pattern sekitar. Bentukan konteks dan teratur, namun dinamis. Sehingga keberadaan proyek dapat menjadi katalis, serta meningkatkan citra kawasan. Kegiatan dimaksimalkan untuk empat kelompok utama yaitu; pedagang, pembeli, warga, dan komuter. Kesimpulan perancangan, adalah Loka Loak Kebayoran Lama, dengan area pasar loak sebagai titik kegiatan jual beli, berpadu dengan fungsi edukasi serta entertainment, yang bertautan dengan fungsi pendukung kegiatan transit. Aktivitas tidak hanya sebatas jual beli, namun juga edukasi dan hiburan. Proyek dapat menjadi tempat kegiatan yang beragam, dan ruang publik baru di titik negatif dalam kawasan urban yang aktif.
\end{abstract}

Kata kunci: loka-loak Kebayoran Lama; pasar loak; pusat transit; third place; urban retrofitting

\begin{abstract}
The existence of transit hubs is a prominent feature of urban life that hold human movement and interaction, which raises the growth of new places for communities, and a third place that was formed naturally. Kebayoran Lama Utara, which located close to a train station, is not spared by this phenomenon. The place becomes unique by flea markets that sprawls among the hub, forming an image for the site, which unfortunately placed where it should not be. It becomes an irony, where a distinctive feature of a place is so potential to be developed, but also becomes the 'parasite' of the area itself. Especially with the fact that the site is located in the negative point of the city, but with a lot of human activities. Loka Loak Kebayoran Lama, with urban retrofitting method, aims to develop the area, both within the site, as well as the surrounding and the communities in one system, to fulfill the functions both socially and economically, but also environmentally sustainable. The project also inspired and maximized the surrounding situation, with the use of an abandoned shophouse as a base structure, and the approaches to the urban patterns. Project is designed to be context to the surroundings, but also dynamic. So, the existence of the project doesn't become the 'alien' of the area, but the catalyst, and improves the image of the region. Activities on the project are maximized to be enjoyed by four main groups which are; the merchants, vendees, the locals, and the commuters. Commercial area to gather the buying and selling activities, combined with the education and entertainment programs, which also linked to the supporting functions for the transit activities. These programs make the project can be a place with diverse activities, and also a new public space at a negative point in an active urban area.
\end{abstract}

Keywords: flea market; loka-loak Kebayoran Lama; third place; transit hub; urban retrofitting 


\section{PENDAHULUAN}

\section{Latar Belakang}

Pertumbuhan transportasi umum massal di Indonesia, terutama di lingkup area Jabodetabek semakin meningkat seiring dengan perkembangan ekonomi, budaya, serta aktivitas masyarakat yang semakin beragam. Hal ini dibuktikan berdasarkan Badan Pusat Statistik Provinsi DKI Jakarta (Statistik Transportasi DKI Jakarta, 2018), dimana jumlah komuter Jabodetabek semakin tinggi hingga mencapai 3.566.178 orang, dengan kenaikan yang tinggi pada penumpang kereta api sebesar 13,48 persen per tahun. Keberadaan suatu pusat transit yang menjadi tempat perpindahan masyarakat antara first place dan second place, kemudian pun turut serta merubah kehidupan masyarakat disekitarnya. Stasiun kereta api, dengan keberadaannya tersebut, menyebabkan area sekitar turut berkembang, seiring dengan munculnya pencari nafkah yang muncul sebagai reaksi atas ramainya aktivitas manusia di stasiun tersebut, yang secara tidak langsung juga turut menjadi ruang bersama baik bagi pengguna moda kereta dan juga masyarakat sekitar seperti yang terlihat pada gambar 1 dan gambar 2.

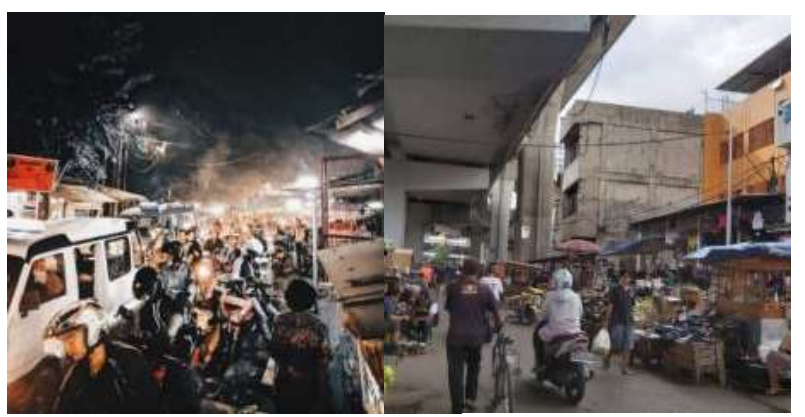

Gambar 1. Area Samping Stasiun Sudimara Sumber: @adyatmaadam,2019
Gambar 2. Pasar Kebayoran Lama Sumber: dokumentasi pribadi,2020

Stasiun Kebayoran, yang terletak di kelurahan Kebayoran Lama Utara, tidak luput pula oleh fenomena tersebut. Sebagai suatu area 'perantara' antar moda dan kawasan yang ramai oleh mobilitas manusia didalamnya. Tak dapat dipungkiri, lingkungan di sekitar stasiun pun ikut menyesuaikan dengan munculnya titik-titik berjualan yang turut menjadi citra dan daya tarik kawasan ini. Lokasi tapak terletak di kelurahan Kebayoran Lama Utara, yang merupakan 'rumah' dari produk-produk jual-beli yang beragam; dari pasar tradisional yang menjual kebutuhan rumah tangga, penjaja barang-barang bekas baik yang mentah ataupun sudah terolah, produk atau karya seni antik, serta pakaian-pakaian bekas atau second hand. Dengan berbagai produk yang ditawarkan, maka akan menarik apabila potensi tersebut dapat dijadikan ciri dan citra bagi kawasan.

Sebagai kawasan yang memiliki potensi yang cukup kuat, Kebayoran Lama Utara menjadi salah satu titik menarik di Jakarta Selatan yang bahkan diesbut sebagai ikon Jakarta Selatan dan sempat diisukan menjadi tujuan wisata. Pemanfaatan produk-produk barang bekas, dan loak (thrifting) sebagai hal yang didongkrak dapat menjadi identitas baru bagi kawasan, dan dapat memberikan pengalaman berkunjung yang unik. Namun ironisnya, para penjual tersebut tidak didukung dengan sarana dan prasarana, serta titik-titik berjualan yang berada di tempat yang tidak seharusnya, sehingga menciptakan suatu ruang di kota yang abu-abu. Sebuah tempat penuh potensi dan cerita, namun tidak seharusnya berada.

\section{Rumusan Permasalahan}

Berdasarkan latar belakang diatas, rumusan masalah yang didapat, antara lain:

a. Bagaimana proyek yang berada di titik padat dan tidak sesuai fungsi dapat memenuhi kebutuhan akan third place bagi masyarakat sekitar tapak ? 
b. Bagaimana menciptakan third place yang dapat 'memperbaharui' fungsi tapak, serta turut membantu dalam pemenuhan kebutuhan masyarakat sekitar tapak?

c. Bagaimana sebuah third place dapat meningkatkan potensi dan citra bagi kawasan yang telah memiliki kekhasan yang cukup kuat, terutama dalam konteks ini yaitu loak dan thrift?

\section{Tujuan}

Sebagai sebuah wadah untuk mewujudkan third place dalam kawasan, proyek memiliki beberapa tujuan yang ingin dicapai, antara lain:

a. Menyediakan fungsi dan program dalam proyek yang dapat menciptakan kawasan yang lebih sehat dan tepat guna, sesuai dengan peraturan yang berlaku, dan juga menyatu dengan masyarakat sekitar.

b. Memberikan ruang publik baru bagi masyarakat di sekitar tapak, sekaligus tempat bersosialisasi dan bercengkrama untuk komunitas-komunitas, serta khalayak.

c. Menyediakan wadah bagi para penjaja barang bekas atau thrift untuk lebih berdaya, sekaligus mengembalikannya ke tempat yang lebih tepat.

d. Memenuhi kebutuhan untuk 'singgah' sementara bagi para komuter yang rehat, dan bertransit.

e. Memberikan edukasi akan kemanfaatan barang-barang bekas, sekaligus tempat menyalurkan minat masyarakat terhadap barang-barang antik atau thrift, dan kegunanannya dalam pembangunan kehidupan yang berkelanjutan.

\section{KAJIAN LITERATUR}

\section{Ruang Publik}

Perbedaan kualitas ruang kota atau kawasan dipengaruhi oleh kualitas ruang publik dan tingkat sosial masyarakat (Darmawan, 2005). Sebagai salah satu aspek penting dalam kehidupan masyarakat urban, ruang publik menjadi penting dalam proses aktualisasi diri, relaksasi, serta sosialisasi manusia, terutama di tengah rumitnya kehidupan kota yang berjalan semakin cepat. Sebagai satu kesatuan yang tidak dapat terputus dari kehidupan manusia, Hildebrand Frey (Frey, 1999) mengkaitkan kebutuhan kota dengan kebutuhan dasar manusia (hierarki Maslow (Gambar 3)), yaitu sebagai berikut:

a. Pada tingkat dasar, kota menyediakan media untuk kebutuhan fisik masyarakat yaitu; tempat tinggal (first place) dan tempat bekerja (second place).

b. Pada tingkat kedua, kota memperhatikan aspek keselamatan, keamanan dan perlindungan.

c. Pada tingkat ketiga, kota menciptakan lingkungan sosial yang kondusif., dalam upaya membuat masyarakat dapat bersosialisasi, berkomunitas, dan memiliki rasa kepunyaan terbadap lingkungannya.

d. Pada tingkat ke-empat, kota dapat memberikan kesan, dan reputasi baik yang dapat menggambarkan penghuninya.

e. Pada tingkat kelima, kota dapat memberikan kesempatan bagi masyarakat untuk berkreasi dan mengekspresikan diri.

f. Pada tingkat terakhir. fasilitas kota merupakan karya desain yang baik, estetis, dan memberi kesan yang mendalam.

Berdasarkan hal tersebut diatas, maka untuk menciptakan kota yang dapat memenuhi kebutuhan masyarakat, selain rumah sebagai first place dan tempat bekerja sebagai second place, dibutuhkan ruang 'antara' yang dapat menjadi tempat manusia mendapatkan unsurunsur lain dalam kebutuhan dasar manusia, yaitu tempat menyalurkan aspirasi, aktualisasi, dan juga berkomunitas, yang dapat dikatakan sebagai tempat ketiga (third place). 


\section{Open Architecture as a Third Place}

Third Place berdasarkan ranah social behavior, adalah tempat netral dan informal, yang menjadi ruang untuk berinteraksi, berkspresi, berpikir, dan bertukar pikiran yang dapat digunakan oleh siapa saja, dan untuk aktivitas apapun, serta terletak diantara First Place yang adalah rumah, dan Second Place yang menjadi tempat bekerja.

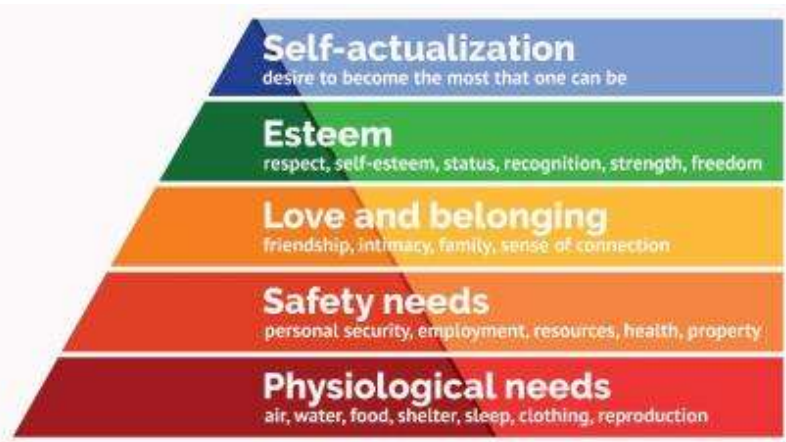

Gambar 3. Piramida Abraham Maslow dan Kaitannya dengan Kebutuhan Dasar Manusia Sumber: simplypsychology.org

Berdasarkan The Great Good Place, third place memiliki beberapa ciri seperti sebagai berikut: (Oldenburg, 1997)

a. They are neutral; third place dapat menjadi area netral di tengah lingkungan atau kota dengan segala keberagaman dan perbedaannya. Orang datang dengan bebas tanpa takut dengan adanya konsekuensi.

b. They are level; third place tidak eksklusif, area tersebut haruslah dapat diakses semua orang tidak terbatas komunitas dan perbedaan yang berarti. Segala lapisan manusia dari ras, suku, agama, atau tingkat ekonomi dapat datang.

c. Conversation is the main activity; third place menjadi tempat untuk berkumpul, bertemu dan bercengkrama dengan siapapun tanpa ada segala batasan dan pemisah. Orang-orang dapat bebas berekspresi, dan berbagi ide dan pengalaman dengan orang lain.

d. Third places are accessible; third place adalah tempat yang mudah digapai dan dicapai. Tidak terkekang, terbatas, dan terkungkung.

e. Third places have regulars; third place tidak menjadi alien di lingkungan dan dapat menyambut segala pihak.

f. Third places are physically plain and unpretentious; third place mencitrakan kenyamanan dan rasa dekat. Tidak menekan dan mengintimidasi.

g. The dominant mood is playful; third place menghadirkan keceriaan, mengajak pengunjung untuk kembali lagi dan lagi.

\section{Pasar sebagai Ruang Publik}

Menurut $\mathrm{KBBI}$, pengertian dari pasar adalah sekumpulan orang yang melakukan kegiatan transaksi jual-beli. Dengan demikian, maka pasar dapat diartikan sebagai tempat fisik dimana pembeli dan penjual berkumpul untuk mempertukarkan barang dan jasa. Pasar yang ingin dicapai adalah pasar yang tetap mempertahankan ciri tradisional yang berada di kawasan, yaitu dengan adanya transaksi jual-beli secara langsung dan biasanya ada proses tawarmenawar (Malano, 2011). Unsur-unsur tersebutlah yang menjadi daya tarik yang membedakan pasar tradisional, dengan modern yang cenderung kurang memperhatikan komunikasi dan koneksi antar manusia.

Berdasarkan tipologi, pasar tradisional merupakan salah satu bentuk dari ruang publik, karena para pengunjung bebas untuk keluar-masuk ke dalam area pasar. Pasar juga merupakan 
positive space, yaitu area yang bebas dikunjungi oleh masyarakat yang digunakan untuk kegiatan-kegiatan positif.

\section{METODE}

Dalam penyelesaian proyek, diperlukan tahapan-tahapan penelitian dan perancangan demi menciptakan desain yang tepat guna dan bermanfaat bagi penggunanya. Oleh karena itu, dilakukan tahapan penelitian yaitu antara lain:

a. Identifikasi isu dan masalah dalam tapak berdasarkan analisis dan data tapak.

b. Analisis program sebagai penyelesaian isu.

c. Investigasi tapak berdasarkan data, dan analisis.

d. Penerapan konsep perancangan pada desain bangunan, berdasarkan analisis-analisis.

e. Perencanaan zoning dan sirkulasi bangunan pada massa.

f. Transformasi massa bangunan.

g. Konsep struktur dan material dalam desain.

h. Deskripsi desain sebagai hasil akhir desain rancangan.

Metode perancangan yang digunakan sebagai dasar dalam penyelesaian proyek adalah pendekatan urban retrofitting, serta arsitektur berkelanjutan (sustainable architecture), yaitu dengan uraian sebagai berikut.

\section{Urban Retrofitting}

Sebagai suatu kesatuan lingkungan, proyek third place juga didesain berkaitan dengan Urban Retrofitting. Urban Retrofitting pada dasarnya merupakan pendekatan, yang bertujuan untuk mengembangkan area baik di dalam tapak maupun lingkungan sekitar, dan bahkan masyarakat didalamnya sebagai sebuah sistem, agar dapat memenuhi fungsi baik sebagai ruang sosial dan ekonomi, namun juga lingkungan yang berkelanjutan. Retrofitting diimplementasikan untuk mendatangkan ketahanan dan menolong area lingkungan untuk tumbuh, dan bertemu dengan kebutuhan untuk perubahan (Jones \& Williamson, 2009). Untuk mencapai perancangan proyek dengan konsep retrofitting, terdapat beberapa parameter yang digunakan untuk menciptakan lingkungan binaan yang dapat memenuhi aspek sustainability, yaitu antara lain: (Jones \& Williamson, 2009)

a. Meningkatkan fisibilitas.

b. Saling keterhubungan dengan area-area sekitarnya (Local Interconectivity).

c. Meningkatkan permukaan tanah yang dapat menyerap air dan RTH.

d. Meningkatkan kualitas ruang publik.

e. Meningkatkan perumahan yang terjangkau.

\section{Arsitektur Berkelanjutan}

Sebagai usaha untuk mendukung retrofitting dan iklim lokal, proyek juga mengimplementasikan metode arsitektur berkelanjutan sebagai pendekatan. Sustainable Architecture (Arsitektur Berkelanjutan) sendiri adalah sebuah konsep yang mendukung berkelanjutan lingkungan, yaitu konsep mempertahankan sumber daya alam agar bertahan lebih lama, yang dikaitkan dengan umur potensi vital sumber daya alam dan lingkungan ekologis manusia, seperti sistem iklim planet, sistem pertanian, industri, kehutanan, dan arsitektur. Pendekatan ini diambil sehubungan dengan program yang menekankan akan penggunaan kembali barang-barang bekas menjadi benda yang bernilai jual dan berguna, serta didukung dengan semakin berkembangnya tren ramah lingkungan (eco living) di masyarakat yang menjadikan konsep reuse dan recycle tidak hanya sebagai sebuah slogan, namun kebutuhan. Diharapkan dalam pelaksanaannya, konsep sustainable tidak hanya dapat dilihat di program, namun pada pelaksanaan pembangunan dan arsitektur itu sendiri. Sustainable Architecture,memiliki dua tujuan utama yaitu:

a. Bangunan berkelanjutan harus meminimalisir dampak terhadap lingkungan, 
b. Bangunan harus mampu member kontribusi yang positif lingkungan sosial didalamnya, dengan mengatasi kebutuhan masyarakat sementara meningkatkan kualitas lingkungan. Sustainable design sendiri memiliki beberapa komponen-komponen yang patut dipertimbangkan demi mencapai desain yang baik, yaitu; energy, nature, community, material, health and well-being, dan site and land use (Sassi, 2015).

\section{DISKUSI DAN HASIL}

\section{Identifikasi Isu Kawasan}

Kelurahan Kebayoran Lama Utara, Kebayoran Lama, Jakarta Selatan dengan titik moda transportasi dan perpindahan yang padat (stasiun dan halte transjakarta penghubung), memang seringkali dicitrakan sebagai area pasar loak dan antik. Berdasarkan survey, area terutama di sekitar stasiun dipenuhi oleh kios, baik yang terbangun maupun kaki lima, dengan barang dagangan tidak hanya barang antik dan loak rumah tangga, namun hal-hal menarik lain seperti pakaian, mainan, serta buku atau kaset bekas. Produk-produk terutama pakaian atau kaset bekas tersebut tentunya dapat menarik bagi masyarakat, terlebih kalangan generasi muda atau milenial. Terutama dengan tren 'thrifting' yang semakin digandrungi saat ini. Sehingga dapat dipastikan area tidak hanya akan menarik bagi satu komunitas tertentu.

Kios-kios kaki lima biasa akan semakin ramai pada hari sabtu dan minggu, menutupi trotoar dan jalan yang menjadi daya tarik, namun tidak didukung dengan sarana dan prasarana yang memadai, terlebih potensi-potensi tersebut sebenarnya tidak sesuai dengan peraturan yang berlaku. Sehingga menjadi sebuah ironi, dimana sesuatu yang menjadi ciri dan pendukung aktivitas dalam suatu kawasan, menjadi sesuatu yang juga tidak seharusnya berada dalam kawasan tersebut.

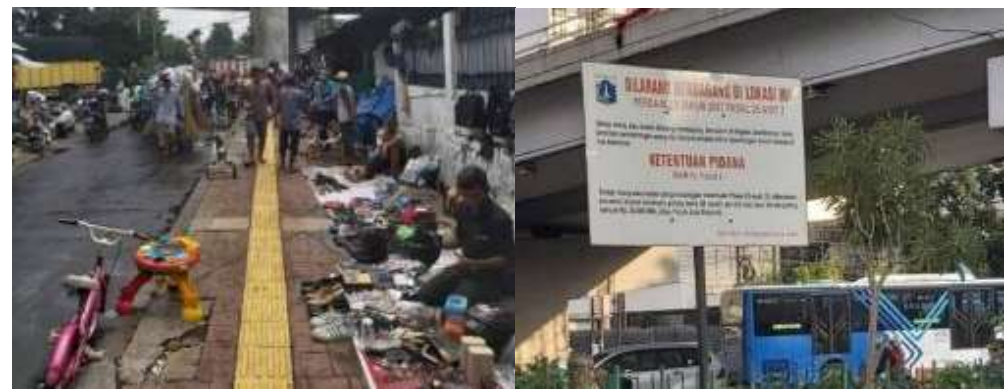

Gambar 4. Kios-kios Pinggir Jalan, dan Papan Dilarang Berjualan Sumber: Dokumentasi Pribadi, 2020

Loka Loak Kebayoran Lama sebagai sebuah proyek, diusulkan untuk menjadi wadah bagi kawasan, yang menjadi media bekerja dan berkomunitas baik bagi para penjaja maupun berbagai lapisan masyarakat lainnya, untuk menciptakan kawasan yang lebih sehat dalam konteks ruang kota, dan menjadi jembatan untuk menciptakan suatu ciri bagi suatu tempat, yang tidak hanya memiliki potensi wisata yang tinggi, namun sebagai sebuah 'sentra'.

\section{Usulan Program}

Tapak merupakan titik yang ramai dan menjadi tempat berkumpul berbagai lapisan masyarakat, terutama penjual atau pedagang pasar, pembeli, warga sekitar, dan juga para komuter Sehubungan dengan hal tersebut, program dibuat agar dapat menampung berbagai lapisan masyarakat tersebut, sekaligus turut mengembangkan ciri serta usaha dan komoditi kawasan, yaitu sebagai area pasar loak. Berdasarkan hal tersebut, program kemudian dibagi menjadi empat pilar utama, yaitu; commercial, education, edutainment, dan program pendukung.

Fungsi Commercial yaitu adalah kegiatan jual beli barang, program menjadi pusat sekaligus pengelola bagi kios-kios antik, barang bekas, baju ataupun komoditi lain yang sebelumnya 
biasa berjualan di tempat yang tidak seharusnya, untuk mendapatkan tempat yang lebih tepat guna. Pasar berkonsep tradisional untuk menjadi konteks dengan sekitar tapak, dimana relasi klasik tawar-menawar masih terjadi, sehingga akan tercipta ruang jual beli yang memperhatikan komunikasi dan koneksi antar manusia. Program juga mendukung masyarakat sekitar, selain penjual juga para industri rumahan di sekitar tapak, terutama yang berkaitan dengan garment.

Dari segi Education, program ingin menekankan penggunaan kembali barang-barang bekas, dengan workshop ataupun kelas-kelas. Dengan workshop atau pameran, program ingin menawarkan pengalaman mengolah kembali barang-barang bekas menjadi suatu bentuk seni yang memiliki nilai jual. Program tersebut selain bermanfaat dalam pemberdayaan masyarakat sekitar, namun juga para pedagang, serta memberi edukasi pula bagi pengunjung secara luas, dan dapat sekaligus mengurangi jumlah sampah terutama yang sulit terurai untuk kemudian dimanfaatkan kembali.

Edutainment sebagai fungsi hiburan sekaligus edukasi, berkaitan dengan area bertemu baik bagi komunitas maupun masyarakat umum, dengan area-area publik yang dapat digunakan sebagai acara komunitas, pameran seni, gallery, atau bahkan fashion show, sehingga nantinya dapat menarik perhatian pula bagi masyarakat umum secara luas, dan dapat menjadi wadah komunitas, serta ruang pertemuan baru bagi masyarakat. Program tidak hanya akan menjadi suatu bangunan yang berdiri sendiri di lingkungan, namun juga dibutuhkan koneksi dan peran dari masyarakat sekitar dalam terciptanya ruang aktivitas yang lebih baik. Kebayoran Lama Utara sebagai rumah dari berbagai industri terutama perdagangan memiliki masalah sampah yang berlarut-larut. Ketiadaan tempat pembuangan sampah disekitar kawasan memaksa baik warga, ataupun para pedagang untuk membuang sampah tidak pada tempatnya (Gambar 5).

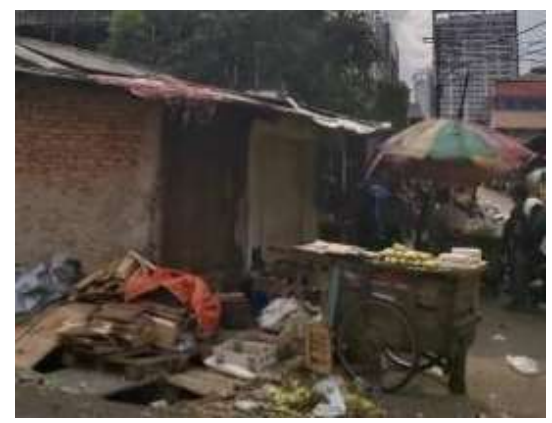

Gambar 5. Tumpukan Sampah di Sekitar Tapak

Sumber: Dokumentasi Pribadi,2020

Sebagai suatu kesatuan dengan masyarakat sekitar, program juga berperan untuk membantu terselesaikannya suatu masalah dalam lingkungan. Dengan keberadaan proyek di kawasan, proyek ingin membuat program yang melibatkan masyarakat dalam hubungan timbal balik pada suatu tapak. Program ingin mengajak masyarakat untuk dapat menyalurkan sampahsampah anorganik, untuk kemudian dijadikan sebagai bahan workshop, material instalasi dan fasad, atau diolah menjadi barang-barang yang lebih bernilai untuk kemudian dijual kembali oleh para pedagang.

Selain hal-hal diatas, sebagai tempat berkumpul dan berbagi ide, dibutuhkan pula programprogram pendukung yang dapat menunjang program utama sebagai sebuah kesatuan dalam lingkungan, terutama dalam pemenuhan kebutuhan para komuter yang ramai di sekitar tapak, seperti fungsi food and beverage, serta coworking space. Fungsi-fungsi tersebut menjadi pendukung kegiatan, terutama bagi masyarakat, dan juga para komuter, yang diharapkan pula 
menjadi konsumen dari kegiatan jual beli atau edutainment. Sehingga aktivitas tidak hanya sebatas jual beli, namun juga edukasi dan hiburan, serta tempat kegiatan yang beragam.

\section{Investigasi Tapak}
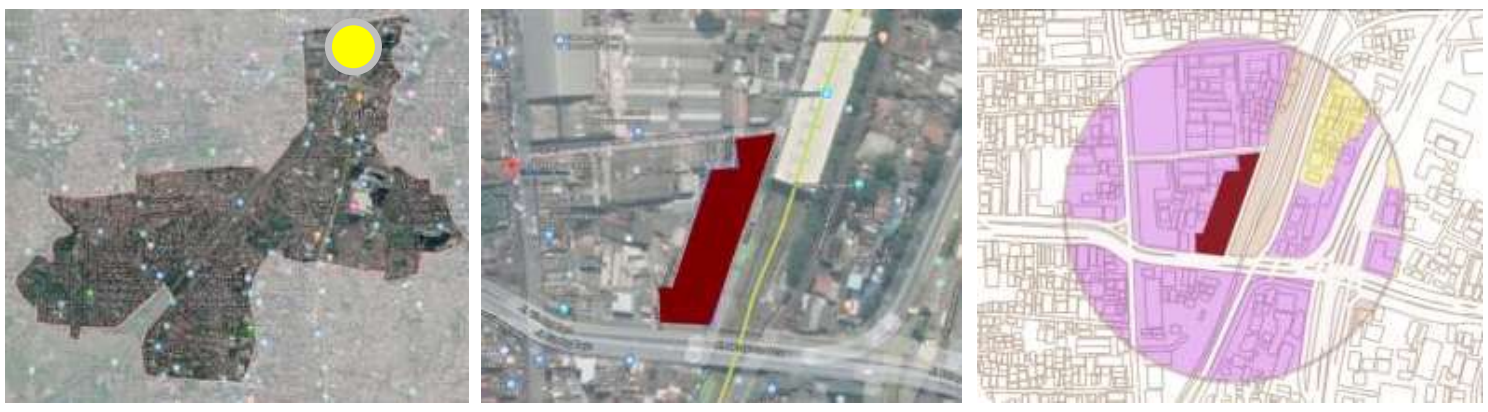

Gambar 6. Lokasi dan Zonasi Tapak

Sumber: Dokumentasi Pribadi, 2020

Pemilihan tapak didasari oleh kesesuaian zonasi sebagai fasilitas perdagangan, serta potensi yang mendukung terciptanya program. Tapak dipilih berdasarkan lokasinya yang berdekatan erat dengan Stasiun Kebayoran sebagai pusat transit serta halte transjakarta Pasar Kebayoran Lama, yang menyebabkan area tersebut menjadi spot yang ramai oleh kegiatan manusia, terlebih dengan lokasinya yang berdekatan dengan pasar kebayoran dan ruko-ruko berjualan. Sehingga, tapak pun menjadi titik tempat berkumpulnya berbagai lapisan masyarakat, terutama para pedagang dan penjual, pembeli, warga sekitar kelurahan, dan para komuter.

Berdasarkan data, tapak terpilih berada di Jalan Raya Kby. Lama, Kebayoran Lama Utara, Jakarta Selatan 12220, dengan spesifikasi sebagai berikut:
a. Luasan Tapak: $4360 \mathrm{~m}^{2}$
b. KDB: 60
c. KLB: 2.4
d. KB: 4
e. $\mathrm{KDH}: 30$
f. Zona: Zona Perkantoran, Perdagangan, dan Jasa
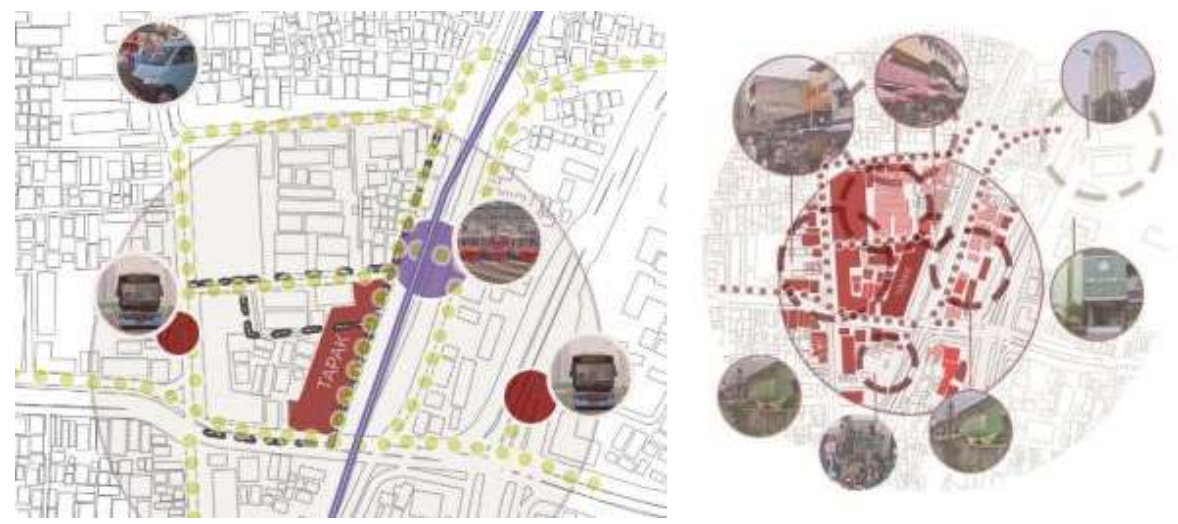

Gambar 7. Pencapaian, dan Fungsi Sekitar Tapak

Sumber: Dokumentasi Pribadi,2020

Tapak eksisting sendiri berada di lahan yang masih terdapat bangunan diatasnya, yaitu berupa ruko terbengkalai dan tidak terpakai. Dengan banyaknya area yang tidak terpakai di tapak, lahan banyak digunakan sebagai area berjualan bagi para pedagang kaki lima, serta tempat pembuangan sampah tidak resmi yang justru malah menjadi masalah di lingkungan sekitar tapak. 


\section{Konsep Perancangan}

Bangunan sendiri memiliki konsep massa yang terinspirasi dengan urban pattern sekitar, dimana fungsi - fungsi dari setiap bangunan membentuk sebuah citra kota. Hal ini digambarkan dalam bangunan, dimana bangunan juga dibentuk oleh fungsi-fungsi ruang di dalamnya, yang dicitrakan dalam bentukan geometris yang menumpuk dan menyusun membentuk sebuah bangunan. Bangunan berusaha selaras dan konteks dengan sekitar yang merupakan bangunan-bangunan ruko dan rumah, namun tetap menampilkan sisi yang dinamis, menggambarkan kesan 'loak' yang acak dan beragam (Gambar 7). Sehingga keberadaan proyek tidak menjadi alien di kawasan namun menjadi katalis, dan dapat meningkatkan citra kawasan.
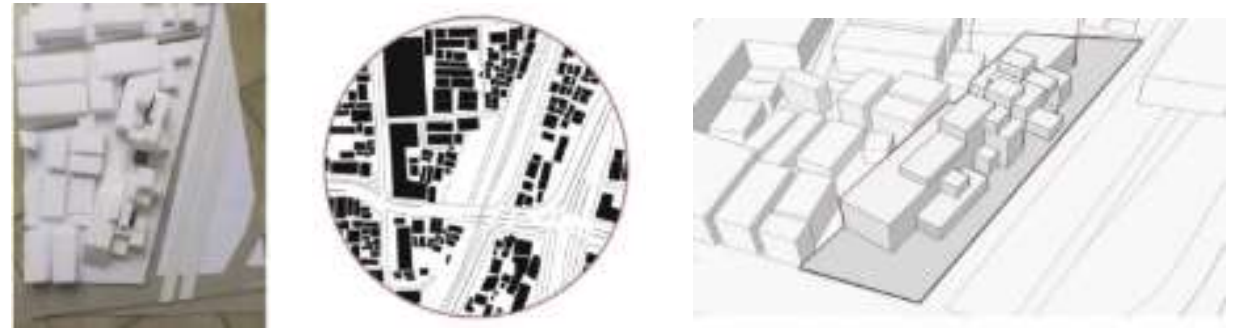

Gambar 8. Urban Pattern, dan Studi Massa

Sumber: Penulis, 2020

Bangunan juga mengusung konsep openness, yang menjadikan keterbukaan sebagai aspek penting. Konsep keterbukaan didasari oleh karakteristik kawasan yang sebagian besar bergerak di sektor komersil, yang menjadikan kebutuhan akan akses dan sirkulasi menjadi penting, dan 'memaksa' bangunan-bangunannya untuk terbuka dan ramah di akses bagi segala kalangan. Terlebih lagi berdasarkan tipologinya, pasar merupakan bentuk ruang publik yang menjadikan pengunjung untuk dapat bebas keluar masuk. Hal ini dicitrakan oleh desain bangunan yang terbuka, terutama dari bentuk dan bukaan bangunan.

Sustainable sebagai konsep juga digalakkan sebagai respon dari bangunan, baik terhadap lingkungan ataupun masyarakat sekitar. Berpadu dengan pendekatan urban retrofitting, yang bertujuan untuk mengembangkan area baik di dalam tapak maupun di lingkungan sekitar dan masyarakatnya dalam satu sistem. Bangunan memanfaatkan struktur dari ruko yang sudah berada di eksisting untuk selain menghemat biaya, juga mengurangi limbah pembangunan yang menjadi masalah tidak hanya di sekitar tapak, namun ibu kota. Bahan-bahan recycle yang terutama berasal dari pasar ataupun fungsi rumah tangga sekitar juga dijadikan sebagai fasad atau aksen - aksen lain di bangunan dalam proses gubah massa.
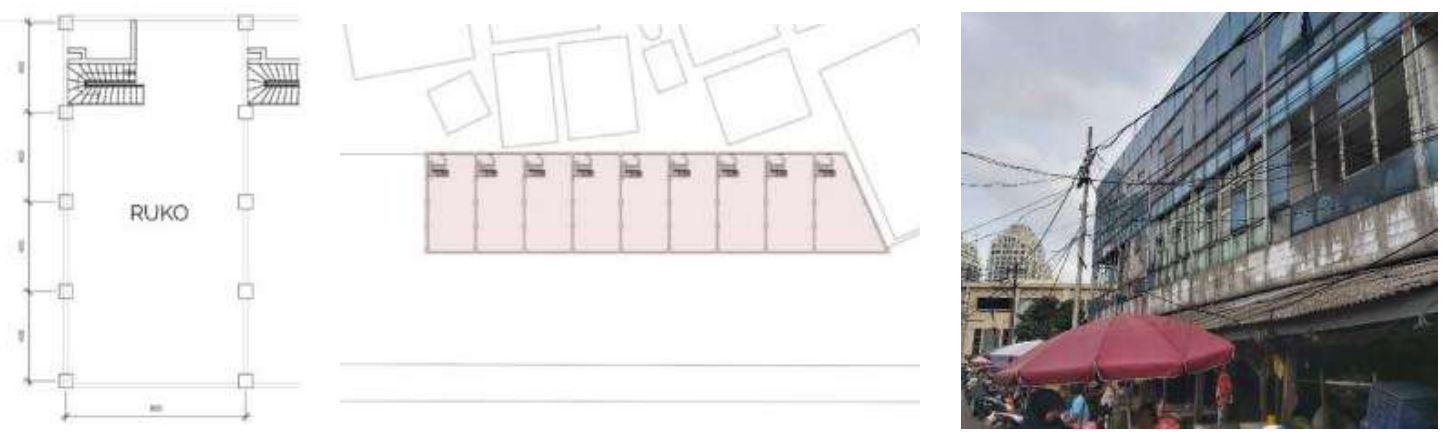

Gambar 9. Dokumentasi Ruko Eksisting Sumber: Dokumentasi Pribadi, 2020 


\section{Zoning dan Sirkulasi Bangunan}

Secara zoning, bangunan dibagi atas fungsinya, yaitu; komersial, edutainment, education, dan pendukung yang digambarkan pada gambar 9 . Lantai dasar digunakan sebagian besar sebagai area komersial, seperti kios-kios serta ruang-ruang perlengkapan untuk menjadikan kesan konteks dan lebih ramah terdapat sekitar yang merupakan pasar, sehingga bangunan akan selaras di lingkungan, terutama dari skala mata manusia. Zona edukasi terletak di sisi barat bangunan, yang bertujuan untuk mendekatkan fungsi-fungsi edukatif yang berkaitan erat dengan penggunaan barang-barang bekas, ke sisi bangunan yang berhadapan dengan jalan kendaraan bermotor untuk memudahkan loading barang dan perlengkapan. Sedangkan, sisi sebaliknya yaitu timur, menjadi zona fungsi pendukung yang berkaitan dengan fasilitas bagi para komuter, untuk memudahkan akses langsung dari stasiun kereta langsung ke dalam bangunan. Lantai dasar dibuat seterbuka mungkin untuk mengusung konsep openness, serta memberikan permeabilitas pada bangunan. Secara akses, bangunan dibuat membuka ke arah titik-titik ramai, seperti arah sirkulasi kendaraan bermotor, ruko, pasar, dan stasiun kereta api.

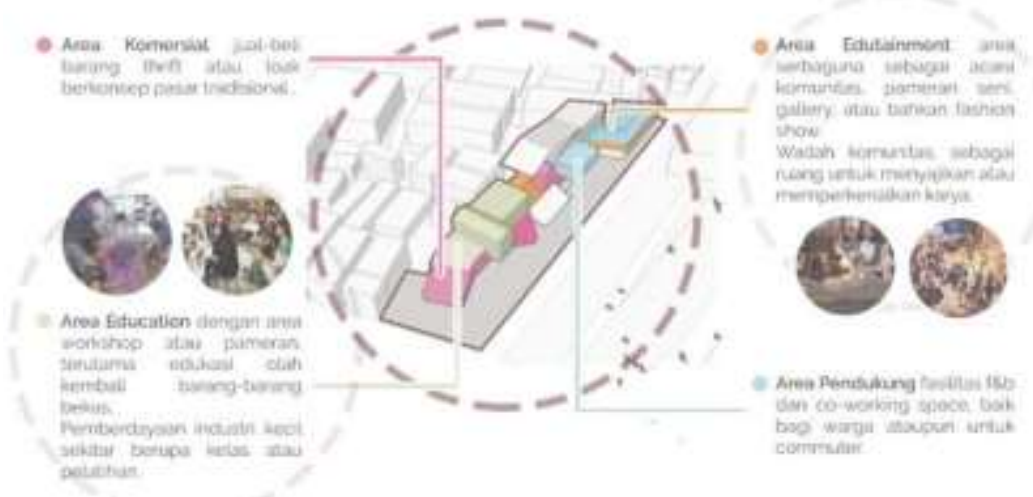

Gambar 10. Zoning Bangunan

Sumber: Penulis, 2020

Akses sirkulasi manusia juga terdapat di lantai dua bangunan, yang didapat dari area tangga di titik satu dan titik dua di gambar 10 . Area tangga (titik 1) menerima sirkulasi manusia dari ruang luar bangunan langsung ke lantai dua. Hal ini sebagai upaya untuk menciptakan kesan open dan permeabilitas pada bangunan, yang erbuka bukan hanya dari ruang luar ke lantai dasar bangunan, namun ke lantai dua, di titik penghubung antara zona edukasi dan zona fungsi pendukung, yang menjadi titik sentral dan dominasi tempat pertemuan para pengunjung, baik para komuter, pedagang, pembeli, ataupun warga sekitar, yang kemudian akan menarik para pengunjung tersebut pula ke fungsi-fungsi lainnya dalam bangunan. Aktivitas dalam bangunan pun menjadi beragam. Lantai dua juga menjadi penerima para komuter dari stasiun langsung ke bangunan, melalui jembatan penghubung yang ditunjukkan pada titik dua di gambar 12 .

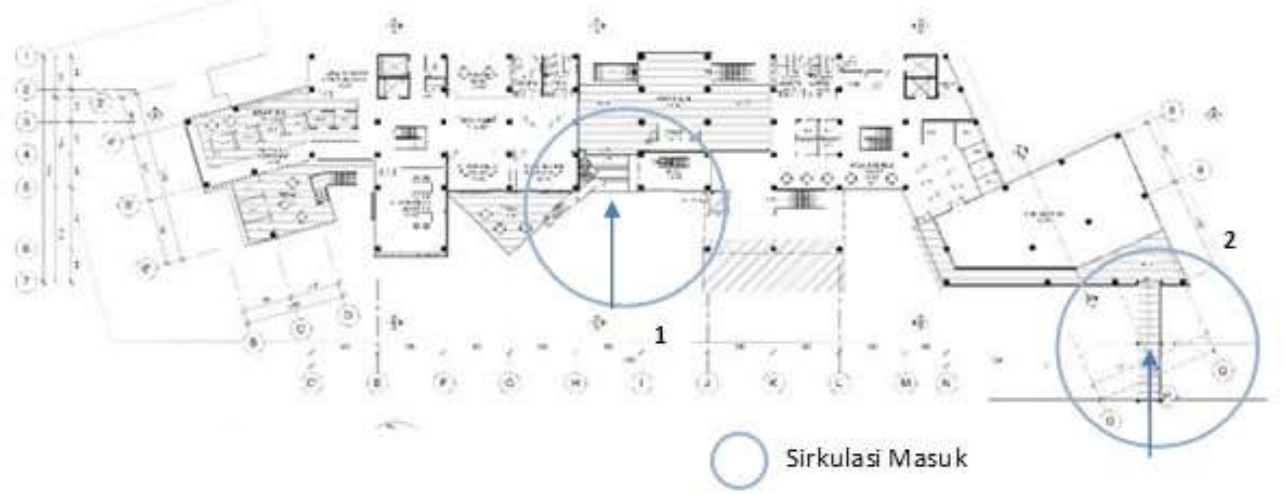

Gambar 11. Denah Lantai Dua

Sumber: Penulis, 2020 


\section{Transformasi Massa}

Berdasarkan hasil analisis, massa digubah dengan proses sebagai berikut; (1) Proses gubah massa diawali dengan massa ruko eksisting sebagai bentuk dasar (base). Massa dibangun dengan tetap mempertahankan sebagian struktur ruko yang ada. (2) Pada tahap selanjutnya, bangunan dibedah untuk menghadirkan permeabilitas yang menghubungkan sisi bangunan dari yang satu ke sisi yang lain untuk menciptakan kesan keterbukaan dan fleksibilitas, dari satu tempat ke tempat lainnya, sekaligus menghubungkan jalan di kedua sisi tapak. (3) Selanjutnya, sebagai respon penyesuaian dari tapak, serta titik keramaian masyarakat, dihadirkan penambahan bentuk massa, sekaligus sebagai extension dari massa awal (4) Ketinggian bangunan kemudian menyesuaikan dengan fungsi, dimana massa meninggi di titik bertanda merah. Sehingga secara visual, bangunan akan lebih ramah dan sesuai dengan skala mata manusia terutama pejalan kaki. (5) Pada tahap selanjutnya, permainan bentukan geometris sebagai konsep massa yang menyusun ditambahkan pada massa, sesuai dengan fungsi kegiatan di dalamnya. Sehingga menimbulkan kedinamisan yang ingin dicapai. (6) Selanjutnya, konsep keterbukaan dengan konektivitas dan kefleksibilitasan antara hubungan ruang luar dan bangunan, serta dari fungsi bangunan yang satu ke fungsi bangunan yang lain, dihadirkan baik dalam bentuk tangga-tangga, permainan peil ataupun ramp, yang sekaligus dapat menjadi ruang publik baru bagi tapak. (7) Tahap gubah massa diakhiri dengan penambahan penutup atap pada bangunan. Penutup atap selain sebagai naungan, namun juga aksen dekoratif, dan pembentuk konsep bangunan yang konteks dengan sekitar, yaitu selain ruko, namun juga rumah-rumah warga sekitar.
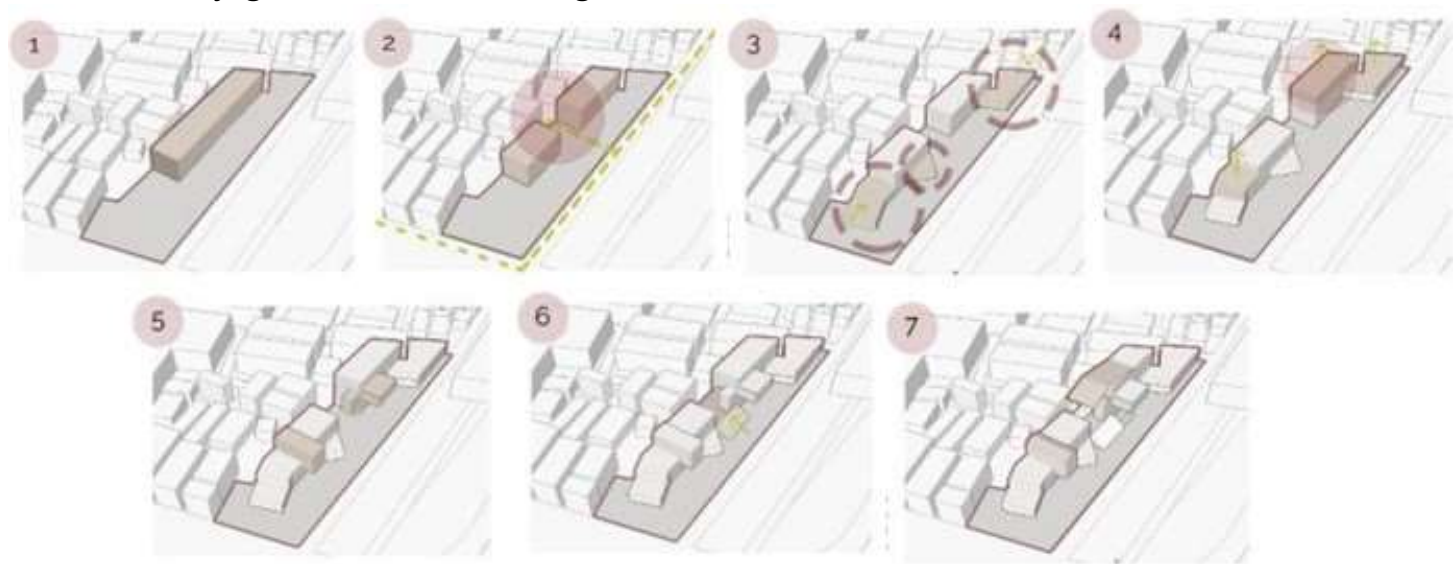

Gambar 12. Transformasi Massa

Sumber: Penulis, 2020

\section{Konsep Struktur dan Material Bangunan}

Secara perancangan, struktur bangunan sebagian besar menggunakan struktur dari ruko yang sudah berada di eksisting. Penerapan adaptive reuse ini sendiri memiliki beberapa manfaat yaitu antara lain: (Sofiana, Purwantiasning, \& Anisa, 2014)

a. Mendukung strategi konservasi dan penghematan sumber daya.

b. Biaya konstruksi yang relatif lebih rendah.

c. Waktu pengerjaan yang singkat.

d. Biaya akuisi lahan yang cukup ringan.

Hal ini pula berkaitan dengan pendekatan sustainable dan retrofitting itu sendiri, untuk mengurangi limbah pembangunan yang marak terutama di kawasan urban, terlebih tapak terletak di kawasan yang cukup padat penduduk. Konsep tersebut pun dimanfaatkan pula pada material dan aksen pada fasad. Bangunan memanfaatkan bahan-bahan recycle yang terutama berasal dari pasar ataupun fungsi-fungsi rumah tangga sekitar, untuk kemudian dijadikan sebagai aksen dekoratif dan pembentuk tampak. 


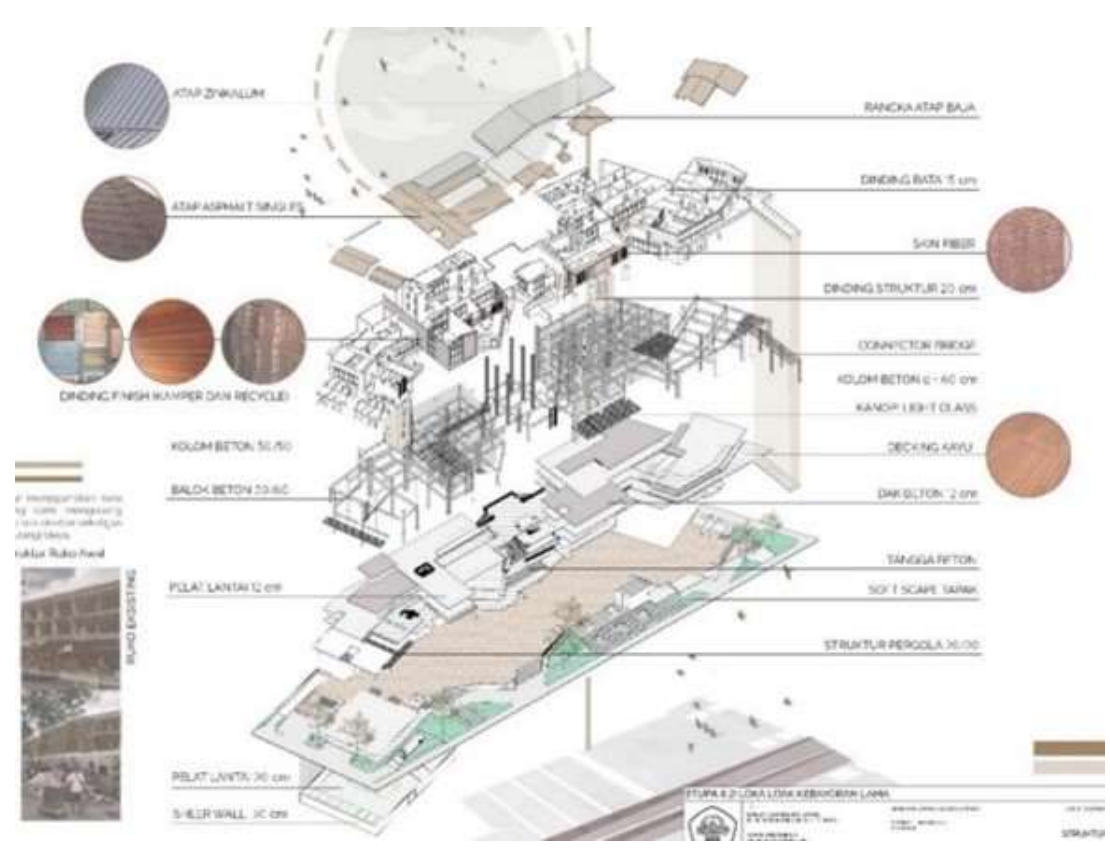

Gambar 13. Skema Struktur dan Material Bangunan Sumber: Penulis, 2020

\section{Deskripsi Desain}

Secara eksterior, bangunan didesain konteks dan tetap mempertahankan keserasiannya dengan lingkungan sekitar, yang sebagian besar merupakan ruko dan rumah warga dengan bentuk yang cenderung ' $b o x y$ ' dan beratap tropis. Bentukan tidak dibuat seakan-akan menjadi alien di tapak, namun menjadi satu dalam kawasan, dengan tetap memberikan suatu ciri dan membentuk kawasan. Desain juga dibuat untuk memberikan kesan keterbukaan dan permeabilitas, baik dengan fasad yang memaksimalkan bukaan, ataupun dengan keberadaan area tangga yang menghubungkan secara langsung area luar dan dalam bangunan, sekaligus dari muka tanah langsung ke lantai lain di bangunan. Area tangga juga menjadi ruang publik yang terintegrasi dengan ruang luar dari bangunan, yang didesain selaras dengan massa proyek yang dibuat seterbuka mungkin, untuk memaksimalkan konsep openness, bagi sebuah third place.

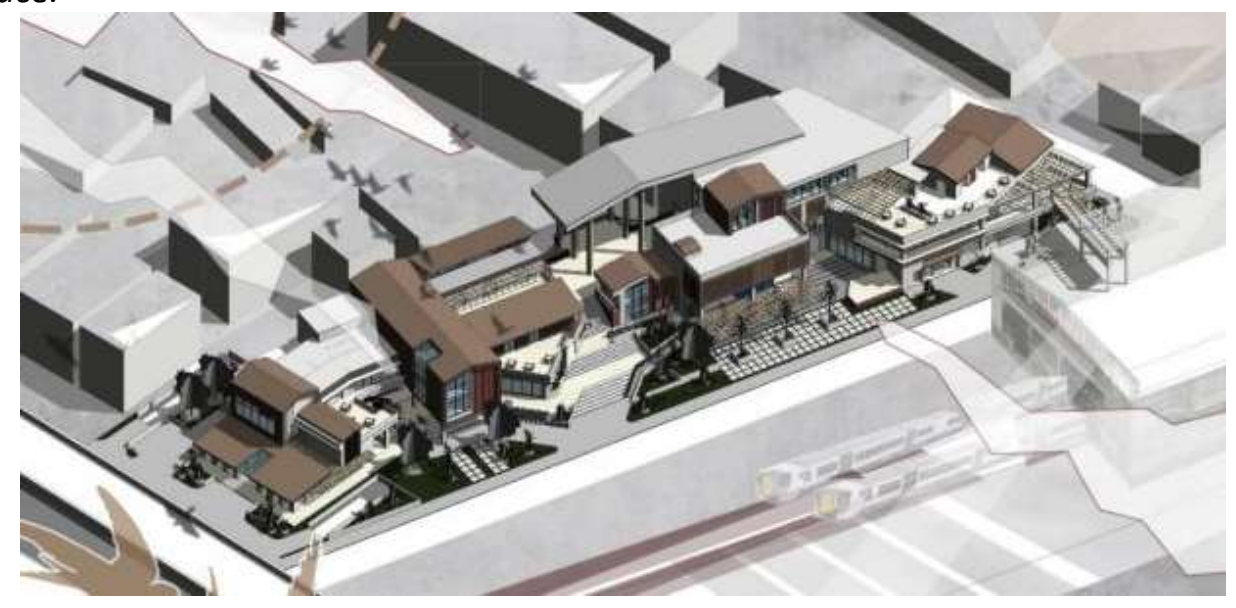

Gambar 14. Tampak Bird Eye Bangunan Sumber: Penulis, 2020 

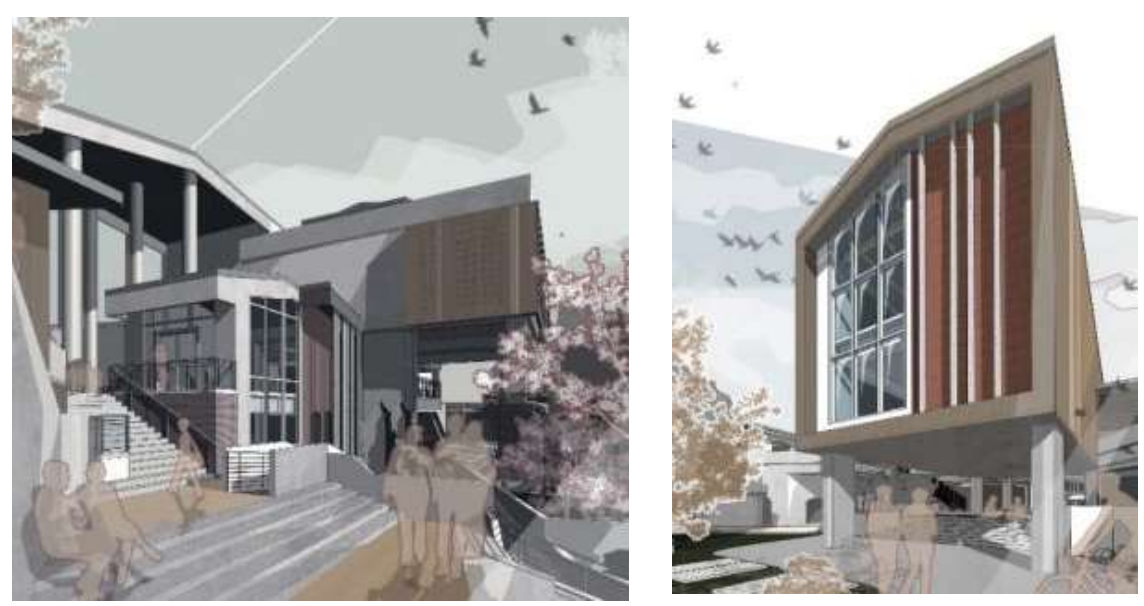

Gambar 15. Area Tangga dan Ruang Luar Bangunan Sumber: Penulis, 2020

Dengan fasad yang terbuka tadi pula, pencahayaan dan sirkulasi udara alami di desain pun dapat dimaksimalkan, terlebih didukung pula dengan bentuk massa bangunan yang cenderung tipis. Material-material bekas sebagai pembentuk fasad dimasukkan selain untuk mendukung konsep keberlanjutan, namun juga secara tidak langsung memberikan identitas bagi bangunan. Ruang-ruang interior, seperti workshop, kelas, dan kios-kios pun didesain memaksimalkan pencahayaan alami, untuk mendukung konsep arsitektur terbarukan. Material penghias interior pun tetap mengusahakan bahan-bahan hias recycle, sebagai pendukung konsep sustainable dan menciptakan citra program yang menekankan daur ulang kepada para pengguna ruangan.

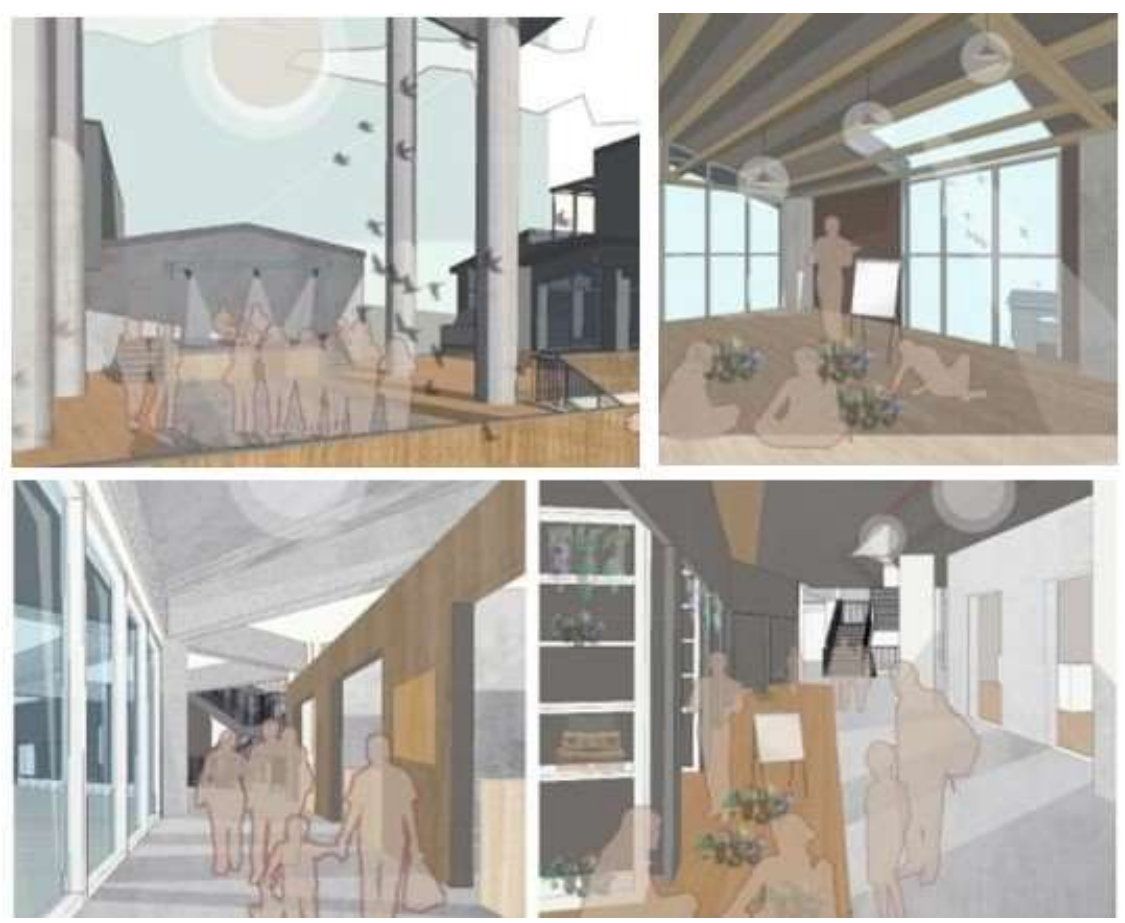

Gambar 16. Interior Bangunan

Sumber: Penulis, 2020 


\section{KESIMPULAN DAN SARAN \\ Kesimpulan}

Proyek dihadirkan sebagai reaksi atas kebutuhan dan juga problem di tapak, yaitu Kebayoran Lama Utara. Tapak yang berada dekat dengan Stasiun Kebayoran sebagai pusat transit menyebabkan kehadiran berbagai lapisan masyarakat yang berkumpul dan berkomunitas di sekitarnya. Munculnya kios-kios serta pedagang kaki lima yang berjualan terutama loak menjadi reaksi atas ramainya aktivitas dalam kawasan, yang turut serta dalam membentuk citra, namun tidak dibarengi dengan fasilitas yang memadai, dan lokasi yang sesuai. Loka Loak Kebayoran Lama sebagai third place ikut mewadahi fenomena tersebut, selain sebagai titik bertemu dan beraktivitas berbagai macam manusia, ditengah sibuknya aktivitas urban yang menjembatani first place dan second place, namun juga menjadi media bagi para penjaja loak dan thrift di sekitar tapak untuk mendapatkan tempat yang lebih tepat guna dan memadai, sekaligus pula menaikkan citra kawasan.

Desain bangunan sebagai sebuah third place didapatkan oleh teori, data, analisis, serta metode-metode perancangan yang terkait, untuk menghasilkan rancangan yang baik dan tepat guna. Metode urban retrofitting dan arsitektur berkelanjutan digunakan sebagai acuan, yang kemudian diikuti oleh tahapan-tahapan dalam perancangan yaitu; investigasi tapak berdasarkan data dan analisis, identifikasi isu dan masalah dalam tapak, analisis program sebagai penyelesaian isu, serta penerapan konsep perancangan. Tahap-tahap tersebut kemudian akan menjadi gubahan yang utuh, untuk selanjutnya direncanakan berdasarkan zoning, sirkulasi, struktur dan material, serta desain secara keseluruhan. Sehingga dapat didapatkan sebuah desain yang dapat menyelesaikan problema dalam kehidupan di sekitar tapak, sekaligus memenuhi konsep third place sebagai salah satu kebutuhan dasar manusia dalam beraktivitas.

\section{Saran}

Kedepannya, diharapkan dengan keberadaan proyek serta potensi kawasan yang sangat tinggi. Kelurahan Kebayoran Lama Utara dapat menjadi salah satu sentra bagi pasar loak, tidak hanya di sekitar kawasan, namun juga ibukota.Terlebih proyek berada di tapak yang berada di area negatif kota, namun ramai oleh aktivitas masyarakat urban. Sehingga, kegiatan dan kebutuhan warga pun dapat terpenuhi, dan dapat membangitkan kesan positif kawasan bagi khalayak ramai.

\section{REFERENSI}

Darmawan, E. (2005). Ruang Publik Dan Kualitas Ruang Kota.

Frey, H. (1999). Designing the City, Towards a more Sustainable Urban Form. E \& FN SPON.

Jones, E. D., \& Williamson, J. (2009). Retrofitting Suburbia: Urban Design Solutions for

Redesigning Suburbs. John Wiley \& Sons Inc.

Malano, H. (2011). Selamatkan Pasar Tradisional: Potret Ekonomi Rakyat Kecil. Jakarta:

Gramedia Pustaka Utama.

Oldenburg, R. (1997). The Great Good Place. Cambridge: De Capro Press.

Sassi, P. (2015). Strategies for Sustainable Architecture. Routledge.

Sofiana, R., Purwantiasning, A. W., \& Anisa. (2014). Strategi Penerapan Konsep Adaptive Reuse Pada Bangunan Tua Studi Kasus: Gedung PT P.P.I (Ex. Kantor PT Tjipta Niaga) di Kawasan Kota Tua Jakarta. Seminar Nasional Sains dan Teknologi 2014 Fakultas Teknik Universitas Muhammadiyah Jakarta.

Statistik Transportasi DKI Jakarta. (2018). Badan Pusat Statistik Provinsi DKI Jakarta. 